\title{
MRI detection of prion protein plaques in variant Creutzfeldt-Jakob disease
}

Figure $\quad$ 9.4T MRI of the postmortem human brain and corresponding histology
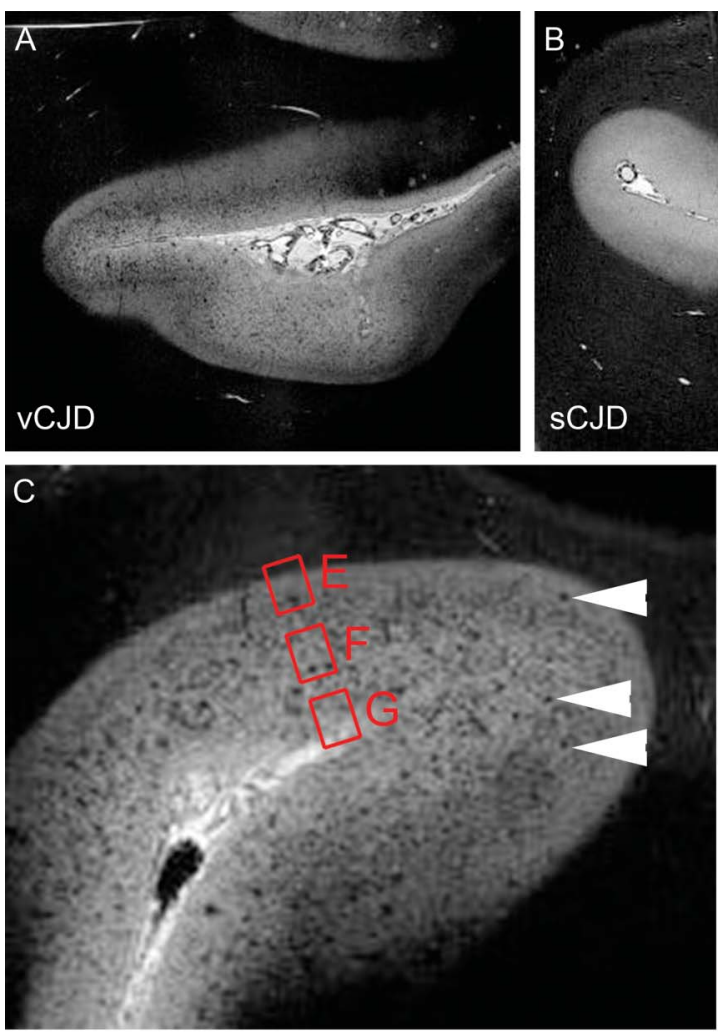

D

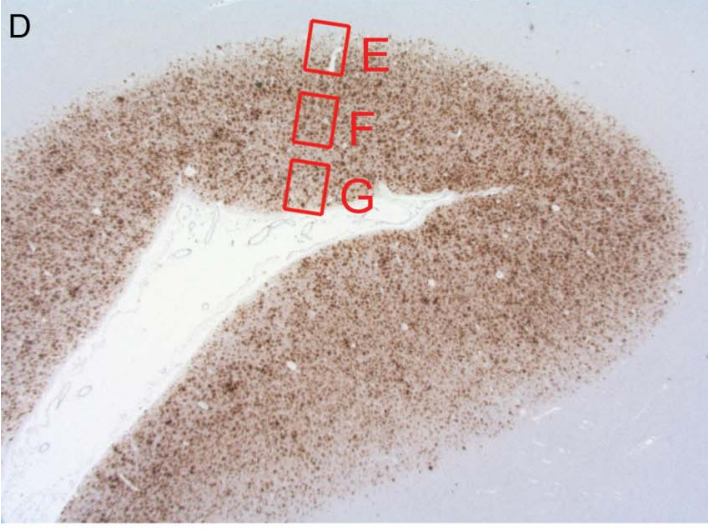

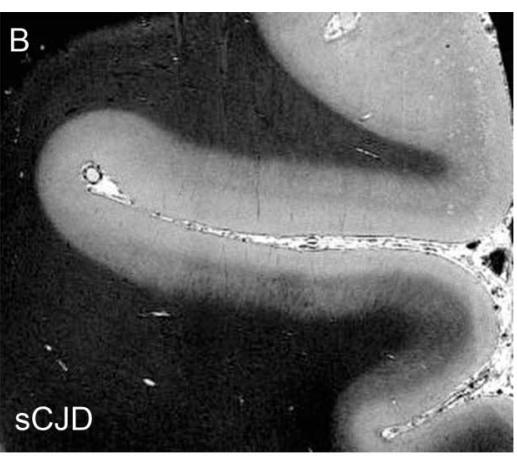

E
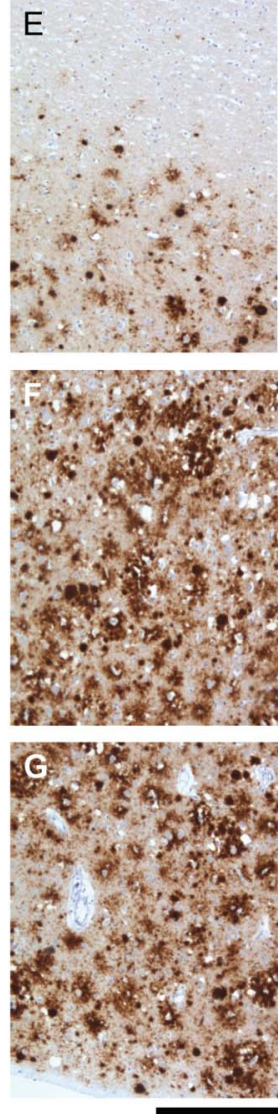

High-resolution ( $58 \mathrm{~mm}$ isotropic voxels) 3D gradient echo sequence (relaxation time $=20 \mathrm{~ms}$, echo time $=5 \mathrm{~ms}$, field of view $30 \times 30 \mathrm{~mm}^{2}$, matrix $512 \times 512,16$ averages) (A, B) and magnified view (C) with corresponding immunohistochemically stained section (D-G). Scale bar: $3 \mathrm{~mm}(\mathrm{D})$ and $200 \mu \mathrm{m}(\mathrm{E}-\mathrm{G})$. sCJD = sporadic Creutzfeldt-Jakob disease; vCJD = variant Creutzfeldt-Jakob disease.

In variant Creutzfeldt-Jakob disease (vCJD), cortical deposition of abnormal prion protein (PrP) aggregates as florid amyloid plaques occur. ${ }^{1}$ The $9.4 \mathrm{~T}$ MRI resolves horizontal laminations of the isocortex. ${ }^{2}$ We scanned blocks of postmortem vCJD brain and a sporadic CJD control after passive staining with gadodiamide using 
a high-resolution 3D gradient echo sequence. Distinct hypointense foci on the MRI in vCJD (figure, A and C) but not control (figure, B) corresponded to PrP-amyloid plaques with greatest density in the central layers of the cortex on histology (figure, D-G). As human high-field systems become widespread, noninvasive monitoring of PrP-amyloid plaques may be of utility in future treatment trials.

Harpreet Hyare, PhD, Po-Wah So, PhD, Sebastian Brandner, MD, John Collinge, PhD, Harold G. Parkes, PhD

From UCL Institute of Neurology (H.H., S.B., J.C., H.G.P.), London; and Kings College London (P.-W.S.), UK.

Author contributions: Harpreet Hyare: experimental design. Po Wah So: experimental design. Sebastian Brandner: interpretation of histologic material, pathologic-radiologic correlation. John Collinge: drafting/revising the manuscript, funding of the study. Harold Parkes: MRI scanning.

Study funding: This work was supported by the UK Medical Research Council. Some of this work was undertaken at University College London Hospitals/University College London, which received a proportion of funding from the National Institute for Health Research Comprehensive Biomedical Research Centres funding scheme.

Disclosure: Prof. John Collinge serves on the editorial boards of Neurobiology of Disease, Journal of Neurobiology, Neurogenetics and Neurodegenerative Disease Management; is a director and shareholder of D-Gen Ltd., an academic spin-out company working in the field of prion disease diagnosis, decontamination, and therapeutics; and receives research support from the UK Medical Research Council, the National Institute for Health Research (England), and the Wolfson Foundation. Go to Neurology.org for full disclosures. Correspondence to Dr. Hyare: Harpreet.hyare@uclh.nhs.uk

1. Collinge J. Molecular neurology of prion disease. J Neurol Neurosurg Psychiatry 2005;76:906-919.

2. Fatterpekar GM, Naidich TP, Delman BN, et al. Cytoarchitecture of the human cerebral cortex: MR microscopy of excised specimens at 9.4 Tesla. AJNR Am J Neuroradiol 2002;23:1313-1321. 


\section{Neurology}

\section{MRI detection of prion protein plaques in variant Creutzfeldt-Jakob disease}

Harpreet Hyare, Po-Wah So, Sebastian Brandner, et al.

Neurology 2015;84;1498-1499

DOI 10.1212/WNL.0000000000000304

\section{This information is current as of April 6, 2015}

\section{Updated Information \& Services}

\section{References}

Subspecialty Collections

Permissions \& Licensing

Reprints including high resolution figures, can be found at: http://n.neurology.org/content/84/14/1498.full

This article cites 2 articles, 1 of which you can access for free at: http://n.neurology.org/content/84/14/1498.full\#ref-list-1

This article, along with others on similar topics, appears in the following collection(s):

Prion disease; see Infections/prion

http://n.neurology.org/cgi/collection/prion_disease

Information about reproducing this article in parts (figures,tables) or in its entirety can be found online at:

http://www.neurology.org/about/about_the_journal\#permissions

Information about ordering reprints can be found online:

http://n.neurology.org/subscribers/advertise

Neurology ${ }^{\circledR}$ is the official journal of the American Academy of Neurology. Published continuously since 1951 , it is now a weekly with 48 issues per year. Copyright @ 2015 American Academy of Neurology. All rights reserved. Print ISSN: 0028-3878. Online ISSN: 1526-632X.

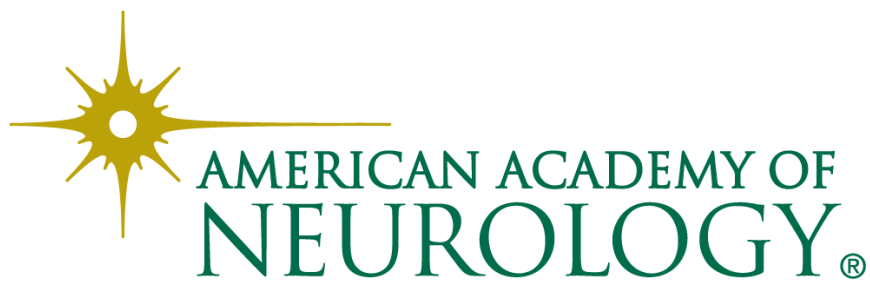

